second class of body, the vegetative granules, which are lightly staining and irregular in form ; and thirdly, the Golgi bodies, only seen in preparations by the silver methods of $\mathrm{Da}$ Fano and Cajal - fairly large polymorphic bodies, often twisted and snake-like, and scattered irregularly in the cytoplasm.

In Nyctotherus the mitochondria ${ }^{2}$ are numerous small rod-like or spherical structures, often showing a well-marked orientation; while the Golgi bodies are larger and irregularly scattered, and vary from rodlike structures to twisted filaments.

Since last January I have been working on Opalina ranarum and Nyctotherus cordiformis, both by means of fixed preparations and intra vitam staining. In some of my silver preparations I find fairly large blackened bodies, more or less round in shape, near the ectoplasm but never in the central regions, and twisted, snake-like in shape. These seem to be the same bodies as identified by Richardson and Horning as Golgi bodies; but I am not convinced that these bodies seen in my formalin silver material are the homologues of the Golgi bodies of Metazoa, both because of their dissimilarity to known types of Golgi apparatus and from failure to show them after many attempts with post-osmication methods (Lassanov, etc.). They may indeed be artefacts.

In chrome-osmium material I find both the rods and irregular bodies, but this also holds after many fixatives, even alcoholic ones; and also all gradations are found between these rods and irregular forms. Hence I have arrived at the conclusion that these are but two aspects of the same structure; they are not mitochondria, but are probably connected with the storage of food. The true mitochondria are small spherical granules, which stain intra vitam with Janus green, as well as being seen in chrome-osmium material.

In Nyctotherus, I have observed the same two categories of bodies as shown by Richardson and Horning; the larger (their Golgi elements), I have fixed with many methods (absolute alcohol, corrosive acetic, Flemming-without-acetic) as well as by silver techniques-slides, so made, were stained by Gram's method, and these bodies were proved to be Grampositive bacteria, exactly like certain bacteria in the rectal contents. For this determination my thanks are due to Prof. Bigger of the Bacteriology Department, Trinity College, who carefully examined my slides. The smaller bodies, mitochondria of Richardson and Horning, were shown by similar fixatives and gave a Gram-positive reaction. It may be that they are mitochondria in which the protein base is particularly well developed, and hence they are not dissolved out by absolute alcohol.

It is hoped shortly to publish a full account of these observations.

Department of Zoology,

Trinity College,

Dublin, July 13.

1 Amer. J. Morph. and Physiol., Sept. 1931.

See also earlier papers of Horning.

\section{Colonisation of the Sea by Insects}

THOUGH insects are represented in almost every possible niche in terrestrial and fresh-water environment, very few indeed have colonised the sea. Besides Halobates, which is pelagic, only some chironomid larvæ and a trichopteron are known to be permanent inhabitants of the sea. ${ }^{1}$ Many insects, however, can live in waters having a salinity equal to and even much higher than that of sea water. ${ }^{2}$ This indicates that salinity is not a barrier to their migration, neither do the ocean currents and tides appear to be, since many insects live in torrential hill-streams which run with almost an equal, if not greater, force and velocity. Furthermore, many insects live on the sea shore ${ }^{3}$ where the physical effects of tides are most pronounced.

In the autumn of 1930 and the spring of 1931, I made extensive collections in several salt waters of the Salt Range, Punjab. I obtained numerous speci. mens of insects from waters of a salinity $\mathbf{2 - 5}$ times as great as that of the sea. These insects included mayfly larvæ (Cloeon sp.) and several hydrophilid beetles. The occurrence of may-fly larvæ in such highly saline waters is, I believe, recorded here for the first time.

A careful comparison of the detailed chemical analyses of waters from the Salt Range area with those of sea-water samples taken by the Challenger from different oceans of the world shows that the most important difference between the two is the comparatively low calcium content $(1 \cdot 16-1 \cdot 20$ per cent) of the sea water. In the salt waters investigated by me the percentage of calcium varied from 1.77 to 31.67, except in the San Sakesar Lake, where it was 0.11 per cent and in which no insect life was found. This definitely suggests that it is the low calcium content of sea water which has stood in the way of insects inhabiting the sea, and that it is the large amount of this ion in the waters of the Salt Range which helps insects in keeping their body fluids in equilibrium with the highly saline waters which they inhabit. This suggestion seems to be strongly supported by the work of Pantin, ${ }^{4}$ Weil and Pantin, and Pantin, ${ }^{6}$ who in the case of estuarine animals showed that calcium has a profound influence on their permeability to water and salts. MeCutcheon and Lucke ${ }^{7}$ found similar factors operating in the case of Arbacia.

I am testing this hypothesis by means of experiments, and the results will be published in due course. My detailed studies on the fauna of some of the salt waters of the Salt Range, Punjab, will be published elsewhere.

Zoological Survey of India

Indian Museum Calcutta, July 20.

1 Buxton, P. A., Proc. Zool. Soc. Lond., 807; 1926.

Balfour, A., Bull. Ent. Res., 12, 29 ; 1921.

3 Flattely, F.W., and Walton, C. L., "The Biology of the Sea Shore", London, 1922

- Pantin, C. F. A., Brit. J. Exp. Biol., 8, 63 ; 1931.

Weil, E., and Pantin. C. F. A., ibid., $73 ; 1931$.

- Pantin, C. F. A., ibid., $82 ; 1931$.

McCutcheon, M., and Lucke, B., J. Gen. Physiol., 12, 129 ; 1928.

\section{Leaf-Curl in Cotton and Other Plants}

IN a recent communication ${ }^{1} \mathrm{Mr}$. Mathur gives an account of his observations on the leaf-curl in garden zinnias, caused by Bemisia gossypiperda Misra and Lamba, at Dehra Dun. The title of the letter suggests that the virus causing leaf-crinkle in cottons in the Sudan is the same that causes leaf-crinkle in zinnias at Dehra Dun. This certainly has not been established so far.

Leaf-crinkle or leaf-curl is not uncommon in cultivated plants. There are in the Punjab, occurring quite commonly, leaf-curls of potatoes, tomatoes, chillies, cucurbits, etc. In the Punjab, however, so far, no leaf-crinkle on cotton has been found associated with $B$. gossypiperda. Just now there is scarcely a cotton leaf which is free from white-fly infestation, yet leaf-crinkle is completely absent.

Leaf-crinkle in cotton should not be confused with leaf-crinkle in other plants without obtaining definite evidence that the same virus is responsible for the disease. M. Afzal Hugain.

Locust Research Laboratory,

Lyallpur, Punjab, July 16.

1 Nature, 129, 797, May 28, 1932.

No. 3278, Vox. 130] 